\title{
Climate change and household welfare in sub-Saharan Africa: empirical evidence from Swaziland
}

\author{
Abdoul G. Sam ${ }^{1} \cdot$ Babatunde O. Abidoye $^{2,3}$ (I) $\cdot$ Sihle Mashaba ${ }^{4}$ \\ Received: 7 February 2020 / Accepted: 5 October 2020 / Published online: 15 October 2020 \\ (C) The Author(s) 2020
}

\begin{abstract}
The fifth assessment report of the Intergovernmental Panel on Climate Change and several studies suggest that climate change is expected to increase food insecurity and poverty in many parts of the world. In this paper, we adopt a microeconometric approach to empirically estimate the impact of climate change-induced hikes in cereal prices on household welfare in Swaziland (also Kingdom of Eswatini). We do so first by econometrically estimating expenditure and price elasticities of five food groups consumed by households in Swaziland using the Almost Ideal Demand System (AIDS), based on data from the 2009/2010 Swaziland Household Income and Expenditure Survey. Second, we use the estimated expenditure and compensated elasticities from the AIDS model, food shares from the household survey, and food price projections developed by the International Food Policy Research Institute (IFPRI) to estimate the proportionate increase in income required to maintain the level of household utility that would have prevailed absent an increase in food prices. Our results show increases in cereal prices due to climate change are expected to double extreme poverty in urban areas and increase poverty in rural areas of the country to staggering levels - between 71 and $75 \%$, compared to $63 \%$ before the price changes. Income transfers of between 17.5 and $25.4 \%$ of pre-change expenditures are needed to avoid the welfare losses.
\end{abstract}

Keywords Climate change $\cdot$ Welfare $\cdot$ Extreme poverty $\cdot$ Demand system $\cdot$ Swaziland

JEL codes Q54 $\cdot \mathrm{Q} 56 \cdot \mathrm{O} 13 \cdot \mathrm{O} 15 \cdot \mathrm{C} 34 \cdot \mathrm{D} 12$

\section{Introduction}

The fifth assessment report of the Intergovernmental Panel on Climate Change (IPCC 2014) concluded that human interference with the climate system is occurring, and climate change

Babatunde O. Abidoye

babatunde@babidoye.com

1 Department of Agricultural, Environmental and Development Economics, The Ohio State University, Columbus, OH, USA

2 Grantham Research Institute, London School of Economics, London, UK

3 University of Pretoria, Pretoria, South Africa

4 Ministry of Economic Planning and Development, Finance Building, Lusutfu Rd, Mbabane, Eswatini poses risks for human and natural systems alike. ${ }^{1}$ The 2014 report also serves as one of the first efforts by IPCC to present a case for the impact of climate change on poverty. Several other studies have addressed the nexus between climate change, food production, and poverty in developing countries. For example, a review by Hertel and Rosch (2010) of research studies using crop growth simulation models and statistical estimations of climate change effects indicates that rising temperatures are expected to significantly reduce cereal yields in low income countries with an attendant increase in household poverty. Results of climate simulations up to 2080 in Onyutha (2019) point to a similar conclusion about the linkage between food insecurity and poverty; thermal environments under future climatic conditions are expected to result in losses in arable land and

\footnotetext{
${ }^{1}$ The conclusion from the AR5 report of the IPCC is that "human influence on the climate system is clear, and recent anthropogenic emissions of greenhouse gases are the highest in history. Recent climate changes have had widespread impacts on human and natural systems."
} 
agricultural output in many parts of Sub-Saharan Africa (SSA). Other related studies focus on the relationship between food prices and poverty through the lens of climate change (e.g., Mkhawani et al. 2016; Seaman et al. 2014; Vermeulen et al. 2012; Brinkman et al. 2010; Baiphethi and Jacobs 2009). Seaman et al. (2014) use a simulation method, the Household Economy Approach, to assess the vulnerability of households to large shocks in cereal prices and production prompted by climate change on household poverty in Malawi and Namibia. In their review of scientific studies about the effects of climate change on food systems, Vermeulen et al. (2012) indicate that climate change will slow down poverty reduction gains in developing countries in part by undermining risk mitigation strategies, investments in agriculture, and through increased food prices which disproportionately affect poor households. In a similar realm, Brinkman et al. (2010) find, not surprisingly, that higher food prices are associated with a reduction in the diversity and frequency of food consumption in Haiti, Nepal, and Niger using a regression model and data collected by the World Food Programme between 2006 and 2008. Baiphethi and Jacobs (2009) discuss changing trends in food supply channels in South Africa-how the infiltration of supermarkets into rural areas has served to lower food prices due to scale economies-and how government subsidies in Southern Africa can improve yields, lower food prices and enhance food security among vulnerable households. A special issue in the Journal Environment and Development Economics (Hallegatte et al. 2018) was devoted to the topic of poverty and climate change. It featured in-depth analyses of the heterogeneous impacts of climate change by income and exposure to environmental shocks at the household level.

Climate change can affect poverty in several ways, including displacement and migration because of climate hazards, impact on food prices, and increased poverty traps through extreme weather events such as pronounced droughts. These channels are interconnected in that displacement and migration from rural areas can lead to reduced agricultural production in said areas, which can spur an increase in food prices. Likewise, an increased likelihood of flooding or drought and lengthening of growing seasons can prompt an increase in real prices as well (Thornton et al. 2010). ${ }^{2}$ In many SSA countries, extreme patterns of climate have the potential to significantly diminish agricultural output (Onyutha 2019; Onyutha 2018), hence worsening the imbalance between supply and demand of food products in the face of fast population growth and low productivity (Ivanic and Martin 2008; Nelson et al. 2010). The regularity of agricultural shocks resulting from extreme weather events in the past decade has led to a rise in food

\footnotetext{
$\overline{2}$ The 2006/2007 food price crisis represents an acute reminder of the impact of climate change on vital commodity prices. One of the two major causes of the 2006/2007 food price spike was droughts in grain-producing nations. "The World Food Crisis". The New York Times. 10 April 2008. Retrieved 29 July 2011.
}

prices which, in turn, has negatively affected most consumers and some producers in the food chain, including farmers, traders of agricultural products, and food manufacturers (Terazono 2014). Wheeler and von Braun (2013) contend that climate change can reverse the gains realized towards the world's goal of eliminating hunger as it reduces the production of crops resulting in increased poverty.

Like many SSA countries, agriculture is a key source of income in Swaziland, with about $75 \%$ of the population engaged in subsistence agriculture on drought-prone land (Burki et al. 2012). More than $50 \%$ of the arable land in the country is used to grow cereal with a high of $70 \%$ in $2014 .{ }^{3}$ According to Mavuso et al. (2015), climate change has resulted in unreliable rainfall patterns, shifted crop growing seasons, and produced very high summer temperatures and dried wetlands. Mavuso et al. (2015) also argued that an increase in food prices would likely cause lower-income net consumers to trade-off necessary nutritious food for lower cost and less nutritious food. Potentially resulting in malnutrition in children and associated irreversible long-term effects. The real costs of using substitute food commodities with lower nutrients will only show at a later stage as the individuals' immune system weakens, and the mortality rate increases (Wodon and Zaman 2010). According to the World Bank, $39.7 \%$ of the population lived under the international $\$ 1.90$ poverty line in 2016 and $2017 .^{4}$ Together, these statistics illustrate the vulnerability of Swazi households to the effects of climate change. According to the World Food Programme Swaziland Country Brief (August 2017), the food security situation in Swaziland was severely impacted by the 2016/2017 El Nino drought. Production of maize was $64 \%$ less than the previous five-year average production in the country that year. ${ }^{5}$ Food prices also remained significantly higher than before the drought. ${ }^{6}$ They estimated that because of the 2016/17 drought, about 159,000 people would need food assistance due to a combination of reduced income opportunities and poor agricultural performance, leading to high reliance on purchases and relatively high food prices.

More closely related to our study are the papers by Dessus et al. (2008), Hertel et al. (2010), and Seaman et al. (2014). Using a similar microeconomic framework as ours, Dessus et al. (2008) provide "back of the envelope" estimates of the effects of the increase in world food

\footnotetext{
3 Authors' computation using data from World Bank's World Development Indicators.

${ }^{4}$ https://www.worldbank.org/en/country/eswatini/overview. Accessed August 19, 2019

5 Authors calculation using data from https://www.indexmundi.com/ agriculture/?country $=$ sz $\&$ commodity $=$ corn $\&$ graph $=$ production. Accessed 2019.08.19

6 Their study concluded that the "most affected population groups are the poor who have lost their crops and have seen their income reduced due to chronic illness or death of bread winner and loss of employment".
} 
prices that started in 2005 on urban poverty in 72 developing countries. The authors conclude that a growth rate of gross domestic product (GDP) between 0.2 and $3 \%$ is required to offset the effect of increased food prices on urban poverty. Unlike our study, however, they do not focus on the impact of climate change, nor do they estimate country-specific substitution elasticities. Instead, they rely on estimates in Seale et al. (2003) to obtain food budget shares and substitution elasticities at the countrylevel. Hertel et al. (2010) and Seaman et al. (2014), on the other hand, explore the effects of climate change on poverty through increased agricultural prices. Hertel et al. (2010) estimates the impacts of agricultural productivity shocks on poverty using the Global Trade Analysis Project (GTAP) general equilibrium global trade model and its accompanying database. Seaman et al. (2014) applied the Household Economy Approach, which relies on a defined reference period in which conditions are known (i.e., a 'good' or 'bad' year). They used it to estimate the expected change in a household's food access from a shock or change in a current 'prediction' year, factoring in the amount of food and non-food goods which the household should be able to obtain, and the types and acceptable use of 'coping' strategies. ${ }^{7}$ In contrast to these two simulation studies, we adopt an econometric approach based on a microeconomic food demand model to study the impact of climate change on poverty at the household level. In addition to disrupting the production cycle, one potential major effects of climate shocks, especially on poor households, is on consumption. Climate shocks destabilize consumption patterns of poor households more so than wealthier households because wealthier households can sell off assets to help smooth consumption while the poor households generally cannot (Hoddinott 2006; Carter et al. 2007; Carter and Lybbert 2012).

The key contribution of this paper is the study of the impact of climate shocks on poverty through consumption expenditure patterns of households using an empirical framework grounded on economic theory. We implement our two-step micro econometric model to quantify the change in household welfare due to climate-induced commodity price increases. Our empirical results for Swaziland suggest that while SSA countries contribute significantly less to climate change, they could bear the brunt of it in terms of increased incidence of poverty and economic decline. Our analysis provides important insights for targeted policy interventions such as social protection or compensation for households most vulnerable to the effects of climate change.

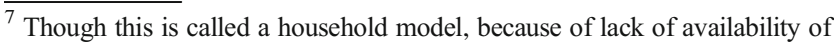
data, many of the models are applied to enumeration area or district level.
}

\section{Background and literature review}

The Kingdom of Swaziland is a landlocked country bordered by Mozambique on the east and South Africa along the north, south, and west of the country. The country is characterized by varying monthly average temperatures with warm to hot summers ranging between 19 and 26 degrees Celsius and winter temperatures between 13 degrees and 20 degrees Celsius. ${ }^{8}$ The country's climate is characterized by seasonal rainfall that varies at higher altitudes from $1000 \mathrm{~mm}$ to $1600 \mathrm{~mm}$ and between $500 \mathrm{~mm}$ and $600 \mathrm{~mm}$ in the lower areas. The country has a wide variety of habitats and significant variations in flora and fauna.

Swaziland is divided into four administrative regions: Hhohho in the north, Manzini in the center, Shiselweni in the south, and Lubombo in the east. Each administrative region consists of regional councils made up of 10 chiefdoms (Mwendera 2006). The Kingdom also has six physiographic zones grouped by elevation, geology, landforms, soils, and vegetation.

In 2010, Swaziland's emission inventory was $0.8 \mathrm{MtCO}_{2} \mathrm{e}$, which represents $0.002 \%$ of global emissions (Swaziland's INDC-Final-UNFCCC 2005). Overall, Africa is responsible for less than $4 \%$ of global greenhouse gas emissions (Sy 2016); yet, climate change is viewed as a serious threat to economic growth in Africa because of the reliance of food production on climate sensitive sectors with limited adaptation to the daunting challenges it poses (Abidoye and Odusola 2015). Knox et al. (2012) project average yield reductions of $17 \%$ for wheat, $5 \%$ for maize, $15 \%$ for sorghum, and $10 \%$ for millet in the African continent by 2050 because of climate change. A higher frequency of drought will increase food insecurity in areas where livelihoods are already precarious. Mendelsohn (2008) argued that the most significant known economic impact of climate change is upon agriculture, especially because farms in the low latitude countries already endure climates that are too hot. Kurukulasuriya et al. (2006) showed that warming is harmful to rain-fed farming in Africa, and rain-fed and irrigated farms both benefit (lose) if rainfall increases (falls). Swaziland's trade ties with an economically powerful neighbor-South Africa-can help cushion some of the negative consequences of climate shocks (Abidoye and Odusola 2015). However, these links do not insulate the country from local price changes and shocks even if they can import cereals from South Africa during droughts as those droughts would lead to an increase in prices in the whole region. Rural communities are more vulnerable to the effects of climate change due to a lack of information on

\footnotetext{
${ }^{8}$ The temperature data is minimum and maximum monthly averages between 1901 and 2009. Author's calculation using data from Abidoye and Odusola (2015).
} 
mitigation strategies and the financial capital to implement them (Manyatsi et al. 2010).

The welfare impact of food price changes depends on the structure of the economy and the nature of the products whose prices change (Ivanic and Martin 2008; Hertel and Winters 2006; Ravallion and Lokshin 2005; Wodon and Zaman 2010; Demeke and Rashid 2012). For example, the severity of the impact depends on the distribution of income and the percentage of net buyers and sellers within the country (Groom and Tak 2015; Ivanic and Martin 2008). It is expected that with an increase in food prices, the pattern of food consumption amongst households will change. Instead of consuming more, households will reduce consumption levels or substitute food commodities towards cheaper goods. D'Souza and Jolliffe (2012) point that we should look at smaller price elasticities per calories rather than per food consumption as most households tend to choose quantity over quality as they shift from consuming highly nutritious food to staple food.

Net consumers of food are most likely the ones affected by higher food prices, especially in urban areas where farming is not practiced (Ravallion 1990; Ivanic and Martin 2008). Ruel et al. (2009) contend that the 2006/7 price and fuel shocks intensively affected the urban poor compared to the rural poor. In a study on the negative impacts of higher food prices in Ghana, Minot and Dewina (2015) stated that female-headed households, who are net-buyers of food commodities, are the most affected by higher food prices compared to male-headed households. This is a consequence of less food production from female-headed households than male-headed households. On the other hand, higher prices are beneficial for households that are net producers, especially in developing countries, where farmers can increase production (Demeke and Rashid 2012). Hertel and Rosch (2010) and Bellemare (2015) also indicate that increases in food prices improve the welfare of net producers while reducing the welfare of households whose consumption is higher than their production. Countries/households that benefit most from price decreases will lose most from price increases, although the net impact may be affected by various policies (trade policy, taxes, etc.), by institutions, and by the industrial organization of the food chain (Centre for Economic Policy Research 2010). Finally, it is noted that in a general equilibrium framework, labor market responses spurred by increasing agricultural commodity prices can also produce positive income effects for farming workers that mitigate the direct impact of the price hikes on consumption (Ravallion 1990; Hertel and Rosch 2010). However, Banerjee (2007) cautions that climate change could depress demand for labor depending on the severity of natural disasters, further weakening the well-being of impacted households.

It is clear from the literature that previous work has mostly concentrated on the aggregate impact of climate change on the agricultural sector as a whole or economic growth in general.
Few empirical studies have drilled down to the household level factoring in both demand and supply of commodities in rural and urban areas. We, therefore, examine empirically the impact of climate change on the welfare of households in Swaziland using IFPRI's projected food prices to the year 2050 (Nelson et al. 2010) in light of the threat of climate change.

\section{Methods and data}

A priori, a household that is a net buyer will experience a welfare loss due to an increase in food prices. ${ }^{9}$ In quantifying changes in welfare, this study follows Friedman and Levinsohn (2002) in estimating the compensating variation $(\mathrm{CV})$, which measures the gain or loss in welfare in terms of the amount of income transfer required for a household to stay on its pre-price change indifference curve. In other words, $\mathrm{CV}$ is the difference between the minimum expenditure necessary to maintain the initial utility level at the new prices and the initial expenditure. Using the IFPRI-calculated projected cereal price changes due to climate change, this study estimates how worse off households become when they move from the initial utility level to utility post-price changes.

Let $c(p, u)$ denote the expenditure function, i.e., the minimum amount of expenditure required to achieve a certain utility level, $u$, at a given price vector $p$. Assume that prices change from $p^{0}$ to $p^{1}$ as a result of the effects of climate change. As mentioned above, the $\mathrm{CV}$ is the difference between the minimum expenditure required to maintain the initial utility level at the new prices and the initial expenditure. Hence it is computed as:

$C V=c\left(p^{l}, u\right)-c\left(p^{0}, u\right)$

The CV can be approximated around initial prices using a second-order Taylor expansion of the minimum expenditure function as follows (see, e.g., Friedman and Levinsohn 2002):

$$
\Delta \ln c \approx \sum_{i=1} w_{i} \Delta \ln P_{i}+\frac{1}{2} \sum_{i=1} \sum_{j=1} w_{i} \varepsilon_{i j}^{*} \Delta \ln P_{i} \Delta \ln P_{j}
$$

where $w_{i}$ is the budget share of commodity $i$ in the initial period (2009/10), $\Delta \ln P_{i}$ approximates the proportionate change in the price of commodity $\mathrm{i}$, and $\varepsilon_{i j}^{*}$ is the compensated crossprice elasticity. Eq. (2) indicates that the impact of a price change can be decomposed into a first order and a second order effect. The first order effect is a function of the

\footnotetext{
${ }^{9}$ As discussed above, increases in agricultural commodity prices could trigger a positive wage response in the long-run that dampens the negative spendingrelated effect of the price increase (Hertel and Rosch 2010; Ravallion 1990). However, in the presence of climate change this positive wage/income effect is not guaranteed; climate change could potentially depress wages for workers creating a "double-whammy" spending and income effect (Banerjee 2007).
} 
magnitude of the proportionate price change and the relative importance of different food groups in the household's consumption basket (captured by the budget shares). It is a measure of the proportionate change in expenditure needed to maintain pre-change utility levels when substitution between food commodities is not possible. As such, the first order effect generally overstates the compensating variation. The second order effect takes into account the fact that households will substitute away from the relatively more expensive good to the cheaper alternatives. The substitution effect is captured by the product between cross-price elasticities of demand and the budget shares. We implement the Almost Ideal Demand System (AIDS) (Deaton and Muellbauer 1980), which is one of the most widely accepted and estimated demand systems in the applied economics literature to estimate the matrix of cross-price compensated elasticities, which we then use to approximate the compensating variation. ${ }^{10}$

Let $w_{i}$ denote $i^{\text {th }}$ commodity budget share, the AIDS is specified as:

$w_{i}=\alpha_{\mathrm{i}}+\sum_{j=1}^{n} \gamma_{\mathrm{ij}} \log \mathrm{p}_{j}+\beta_{\mathrm{j}} \log \left(\frac{x}{P}\right)$

$\log \mathrm{P}=\alpha_{0}+\sum_{k=1}^{n} \alpha_{\mathrm{k}} \log p_{k}+\S \sum_{\mathrm{k}} \sum_{\mathrm{j}} \gamma_{\mathrm{kj}} \log p_{k} \log p_{\mathrm{j}}$

where $x$ is food expenditure, the $\mathrm{p}_{\mathrm{j}}$ 's are food prices, $\alpha_{\mathrm{i}}, \gamma_{i j}$, and $\beta_{\mathrm{i}}$ are parameters to be estimated and $\mathrm{P}$ is the trans logarithmic price index; thus $\frac{x}{P}$ stands for the real expenditure.

To estimate the AIDS model, we use the 2009/2010 Household and Income Survey data collected by the Central Statistics Office (Central Statistics Office 2011) from 375 enumerated areas of the Kingdom of Swaziland. The survey is national in nature with financial and technical assistance provided by the United Nations Development Programme (UNDP) and the Accelerated Data Program that also provided technical support. ${ }^{11}$ While the survey was initially designed to be conducted every 5 years, it has not been implemented since $2009 / 10$, according to the government's website. ${ }^{12}$ The study used the 2007 population census to locate enumeration areas and the primary sampling units. A two-stage stratification sampling method was incorporated in the surveys across both

\footnotetext{
${ }^{10}$ Several studies have used the AIDS model to estimate demand. Lazaro et al. (2017) use it to study the price elasticities of imported vs domestic rice in Tanzania; Grant et al. (2010) study the demand for fresh tomatoes in North America; Wadud (2006) analyse meat demand in Bangladesh; Abdulai (2002) estimate household demand for food in Switzerland; and Chang et al. (2011) study organic milk purchase behaviour in Ohio.

${ }^{11}$ The data was obtained from the statistics office in Eswatini but can also be downloaded from the International Households Survey Network, https:// catalog.ihsn.org/index.php/catalog/4599.

${ }^{12}$ Central Statistics Office. [online] Available at: http://www.gov.sz/index. php/departments-sp-388544304/78-economic-planning-a-development/ economic-planning-a-development/687-central-statistics-office [Accessed 3 Jan. 2020].
}

rural and urban settlements, cutting through all the ecological, administrative, land distribution, and tenure features (CSO 2011). Our final sample is comprised of 3143 households and captures information on both the production and consumption of food products.

Given the broad nature of the food categories, we group the food commodities in five food bundles, as is standard practice in models similar to ours (e.g., Molina 1994; Agbola 2003). For instance, Agbola (2003), in estimating food demand for South Africa, grouped the food items into meat and fish, grains, dairy products, fruits, vegetables, and other foods. Our classification of the food items is closer to that of Agbola (2003), given the similarities in culture across the two countries. We categorize the food items into five groups, namely: (1) cereals, roots, and tubers, (2) vegetables, legumes and nuts, (3) fruits, (4) meat, eggs, fish and dairy products, and (5) other food products. Vegetables and fruits are not combined in line with Agbola (2003) and based on the way food is typically made in Swaziland. Pepper/chili, spinach, and tomatoes, for instance, are consumed with fresh peas, beans, and other nuts. Table 1 details the composition of food commodities found in each food group.

To estimate the demand equation, the annual prices, annual expenditure, and annual budget shares of the five food groups were used. For the annual prices, the total expenditure values given by households on a specific item are used and divided by the number of items bought. The price was then multiplied by 12 to annualize and estimate the change of price over 12 months. For the commodity group prices, the price within the group is weighted by the total number of the items consumed in that group.

Per share statistics in Table 2, the cereals, root and tubers and meat, eggs, fish, and dairy product groups are the two most important food groups, accounting respectively for 31.46 and $25.14 \%$ of food expenditure. The cereal category consists mostly of maize, the staple food of Swaziland. Vegetables, legumes and nuts represent $20.47 \%$ and fruits represent $10.17 \%$ of food expenditure, while the remaining combined category accounts for $12.77 \% .^{13}$

The food consumption expenditures in the survey were collected in a series of diary modules filled daily by household members over a maximum period of 7 days. The diary was also used for "goods and services received" and "own-produce consumption." However, despite the detailed diary of data, some food items were not purchased by the household.

Per Table 3, the food expenditure share remained stable between the survey rounds of 2000/01 and 2009/10, respectively $21.5 \%$ and $21.4 \%$ of the total household expenditure.

\footnotetext{
${ }^{13}$ As is typical of many developing countries especially in the rural areas, many households grow their own fruits and vegetables and may not necessarily spend money buying them even though they may be an important component of their food demand.
} 
Table 1 Composition of food aggregation on consumed food commodities in Swaziland

\begin{tabular}{|c|c|}
\hline Food groups & Food items \\
\hline Cereals, roots and tubers & $\begin{array}{l}\text { Cereal: white bread, brown bread, breakfast cereals, biscuits, cake, wheat flour, } \\
\text { mealie meal (imphuphu), mealie rice, mabele meal, samp (sitambu), } \\
\text { spaghetti/macaroni, sorghum meal, rice, other bread, green-mealie and cereals. } \\
\text { Roots and tubers: cassava, potatoes, sweet potatoes and other starchy tubers. }\end{array}$ \\
\hline $\begin{array}{l}\text { Vegetables, legumes and } \\
\text { nuts }\end{array}$ & $\begin{array}{l}\text { Beetroot, cabbage, carrot, garlic, green pepper, lettuce, mushrooms, okra, onions, } \\
\text { pumpkin leaves, pumpkin and squashes, pepper/chili, spinach, tomatoes, ginger, } \\
\text { turnips, radish, tinned vegetables, fresh peas, beans, other dried vegetables, } \\
\text { frozen vegetables and other fresh vegetables, round nuts, peanuts/groundnuts, } \\
\text { other nuts. }\end{array}$ \\
\hline Fruits & $\begin{array}{l}\text { Apples, oranges, bananas, grapes, avocados, lemon/lime, mangoes, pawpaw, } \\
\text { peaches, pears, pineapple, plums, strawberries, other fresh fruit, tinned fruits and } \\
\text { dried fruits. }\end{array}$ \\
\hline $\begin{array}{l}\text { Meat, fish, eggs and dairy } \\
\text { products }\end{array}$ & $\begin{array}{l}\text { Meat: beef, chicken, turkey, pork, fish, sausages, bacon, polony, ham, goat meat, } \\
\text { mutton, game, rough tripe, offals (ematfumbu), dried / smoked fish, canned or } \\
\text { tinned fish, and other meat. } \\
\text { Dairy: fresh milk, sour milk, skimmed milk, powdered milk, other milk, cheese, } \\
\text { cream., eggs, yoghurt/sip. }\end{array}$ \\
\hline Other food products & $\begin{array}{l}\text { Sugar: glucose, sugar granules, candy sweets, other sweets, syrups and other } \\
\text { sweets. } \\
\text { Oils and fats: butter, peanut butter, lard/dripping, holsum, cooking oil, margarine, } \\
\text { other vegetable oil, other oil and fat. }\end{array}$ \\
\hline
\end{tabular}

Source: Authors' calculations based on data from SHIES (2009/2010)
However, the share of "food received," primarily from food baskets from development aid programs, increased significantly from 2000/01 to 2009/10. Even with the grouping of the data into food categories, none of the five groups was purchased by all households sampled, resulting in zero expenditure. Zero expenditure, in this case, does not mean zero consumption; it simply means that the household did not purchase the product during the survey period either because the household produced the good, received it as a gift, survey period (7 days) being too short or because of household preferences.

If unaccounted for econometrically, zero expenditure leads to biased and inconsistent elasticity estimates (Sam and Zheng 2010) due to censored response bias. We, therefore, implement a consistent two-stage estimator (Shonkwiler and Yen 1999; Sam and Zheng 2010) to circumvent this issue. The first stage consists of estimating a binary single-index model for each commodity to predict its probability of consumption. Suppose we have $L$ household observations on each commodity and suppose that the probability of consuming commodity $i$ by household $l$ is a function of control variables $z_{i l}^{\prime}$ and a normally distributed error term $v_{i l}$. That is $d_{i l}=I\left(z_{i l}^{\prime} \delta_{i}+v_{i l}>0\right)$ where $d_{i l}$ is a binary variable that equals one if commodity group $i$ is consumed by household $l$, zero otherwise; $I\left(\right.$.) is an indicator function and $\delta_{i}$ a parameter vector. To account for the censoring of the commodities, the predicted probabilities of consumption $\Phi\left(z_{i}^{\prime} \delta_{i}\right)$ and inverse mills ratios $\varphi\left(z_{i}^{\prime} \frac{\left.\delta_{i}\right)}{\Phi\left(z_{i}^{\prime}\right.} \delta_{i}\right)$ are computed for each commodity group from the first stage probit and added nonlinearly to the AIDS equation as follows:
Table 2 Total consumption expenditure by households and share of households that consume each food group in Swaziland

\begin{tabular}{lll}
\hline Food group & Expenditure share & $\begin{array}{l}\text { Percentage of households } \\
\text { with non-zero expenditure }\end{array}$ \\
\hline Cereals, roots, and tubers & 31.46 & $95.04 \%$ \\
Vegetables, legumes and nuts & 20.47 & 81.39 \\
Fruits & 10.17 & 56 \\
Meat, fish, eggs and dairy products & 25.14 & 88.26 \\
Other food products & 12.77 & 81.61 \\
Total & 100.00 & \\
\hline
\end{tabular}

Source: Authors' calculations based on data from SHIES (2009/2010) 
Table 3 Household expenditure structure, 2000/01 vs. 2009/10

\begin{tabular}{lll}
\hline SHIES & $2000 / 01$ & $2009 / 10$ \\
\hline Food & $\mathbf{2 7 . 2}$ & $\mathbf{3 0 . 7}$ \\
Food purchased & 21.5 & 21.4 \\
Food own produced and consumed & 3.6 & 4.2 \\
Food received & 2.1 & 5.1 \\
Non-food & $\mathbf{7 2 . 8}$ & $\mathbf{6 9 . 3}$ \\
Total & $\mathbf{1 0 0 . 0}$ & $\mathbf{1 0 0 . 0}$ \\
\hline
\end{tabular}

Source: Swaziland HIES 2009-2010 poverty report, Poverty in a decade of slow economic growth: Swaziland in the 2000's

$w_{i}=\Phi\left(z_{i}^{\prime} \delta_{i}\right)\left(\alpha_{i}+\beta_{i} \log \left(\frac{x}{P}\right)+\sum_{j=1}^{n} \gamma_{i j} \log p_{j}+\theta_{i} \frac{\varphi\left(z_{i}^{\prime} \delta_{i}\right)}{\Phi\left(z_{i}^{\prime} \delta_{i}\right)}\right)+\zeta_{i}, i=1, \ldots \ldots n$

As commonly done, the five censored AIDS equations are estimated as a system of seemingly unrelated regressions. ${ }^{14}$ The expenditure and uncompensated (Marshallian) elasticities are calculated from the parameters of the AIDS model, respectively, as follows: $\mathrm{e}_{\mathrm{i}}=1+\Phi_{i} \frac{\beta_{\mathrm{i}}}{w}$ where $\Phi_{i}$ is the estimated probability of consuming food category, and $e_{i j}=\Phi_{i}$ $\left(\frac{\gamma_{\mathrm{ij}}-\beta_{\mathrm{i}}\left[\mathrm{w}_{\mathrm{j}}-\beta_{\mathrm{j}} * \log \left(\frac{x}{P}\right)\right]}{w_{\mathrm{i}}}\right)-\mathrm{s}_{\mathrm{ij}}$ where $\mathrm{s}_{\mathrm{ij}}$ is a dummy that equals 1 if $\mathrm{i}=\mathrm{j}$; 0 otherwise (Sam and Zheng 2010).

\section{Results}

Before discussing the results, we present summary statistics of the key variables in the model in Table 4. The average household size is about 5 , and household heads are about 45 years old on average. The sample has more male $(55 \%)$ than female household heads and is more rural $(56.5 \%)$ than urban. On average, households spend a significant share of their food expenditure on Cereals,

\footnotetext{
$\overline{14}$ To estimate the first and second stage of the AIDS model, we include several demographic variables of the households in addition to prices: age and gender of the household head, a dummy indicating if the household resides in a rural or urban area, five dummies indicating if the household produces each of the five food categories listed in Table 1, and dummies representing the three of the four regions of Swaziland (Hhohho, Manzini, Shiselweni and Lubombo). For identification purposes, the first stage includes an additional variable that is not in the second stage: income decile (Sam and Zheng 2010). We follow Pudney (1989) and other studies in the consumer demand literature such as Lazaro et al. (2017), Bilgic and Yen (2013), Yen and Lin (2006) in not including prices and food expenditure in the probit but we include total household income in the form of income deciles. Omitting prices in the Probit equations is a reasonable approach when the zero purchases are driven by non-price factors such as shortness of the survey period, availability of the goods, or inherent household preferences.
}

root and tubers and Meat, fish, eggs, and dairy. Fruits have the lowest share of household food expenditure. The food group made of meat, fish, eggs, and dairy products is produced by most households (54\%), while fruits are only produced by $10 \%$ of the households. Commodity group prices are obtained as a weighted average price of the food components for each group with the individual commodity expenditures serving as weights.

In addition to the summary statistics at the national level, we also present summary statistics by region (Table 5). Household size, for instance, is highest in the Shisel region of the country at 5.4 people per household. The second highest average household size is in Lubomb region at about 4.6 people per household; in contrast, Hhohho has the smallest average household size at 4.0. There is also heterogeneity in the level of prices across the regions based on the combination of commodities in each group. For instance, Lubomb region has the highest annual average price (SZL/Kg.) for group 1 foods (cereals, roots, and tubers) at $1.32 \mathrm{SZL} / \mathrm{Kg}$ but with more substantial variation in the prices. Prices are lower in Hhohho region, and the standard deviation is also lower. In terms of production of the different food categories, it can be seen from Fig. 1 that households in the Shisel region produce the highest percentage of meat, cereal, vegetable, and fruit products which likely leads to lower consumption expenditure on these goods in this region relative to the other areas. Cereal production by households is about the same in the other three regions, but Luhomb is the second producer of fruit and vegetable products.

\subsection{First stage results}

The IFPRI price projections used in the analysis are conducted at a global level based on the price of mostly consumed food crops such as cereals (maize, wheat, and rice). The projections were from 2010 to 2050, a period of 40 years. Unlike Nelson et al. (2009), which projected future outcomes of climate change and price increases using only GDP and population, these projections utilized a combination of income and population growth to estimate the outcomes in 3 scenarios: a baseline scenario to represent the most likely outcome of status quo income and population growth, an optimistic scenario that is likely to result in low population and high-income growth rates, and a pessimistic scenario with more negative outcomes for human well-being with high population and low-income growth rates. Each of these scenarios is subjected to five plausible climate futures that range from slightly to substantially wetter and hotter on average than the current climate representative concentration pathways 
Table 4 Demographic and other variables used to estimate parameters in the demand system

\begin{tabular}{|c|c|c|c|}
\hline Variable & Description & Mean & $\begin{array}{l}\text { Standard } \\
\text { deviation }\end{array}$ \\
\hline Region & Hhohho, Shiselweni, Manzini and Lubombo & & \\
\hline Location & Urban/Rural & 0.5651 & 0.4958 \\
\hline Hhsize & Household size & 4.4747 & 3.2759 \\
\hline Head age & Age of the household head & 444.9857 & 15.7680 \\
\hline $\begin{array}{l}\text { Head } \\
\text { gender }\end{array}$ & Male (1) or Female (0) household member & .5476 & 0.4978 \\
\hline$\underset{\text { exp1 }}{\text { Ann_hh }}$ & $\begin{array}{l}\text { Annual household expenditure (SZL) of food group } 1 \text { (Cereals, } \\
\text { roots, and tubers) }\end{array}$ & $40,168.02$ & $55,082.18$ \\
\hline$\underset{\text { exp2 }}{\text { Ann_hh }}$ & $\begin{array}{l}\text { Annual household expenditure (SZL) of food group } 2 \text { (Vegetables, } \\
\text { legumes and nuts) }\end{array}$ & $11,313.46$ & $19,261.12$ \\
\hline$\underset{\text { exp3 }}{\text { Ann }{ }_{\text {h }}}$ & Annual household expenditure (SZL) of food group 3 (Fruits) & 4684.88 & $11,944.17$ \\
\hline$\underset{\text { exp4 }}{\text { Ann } h \text { h }}$ & $\begin{array}{l}\text { Annual household expenditure (SZL) of food group } 4 \text { (Meat, fish, } \\
\text { eggs and dairy products) }\end{array}$ & $44,740.62$ & $60,456.73$ \\
\hline$\underset{\exp 5}{\mathrm{Ann}{ }_{\mathrm{C}} \mathrm{hh}}$ & $\begin{array}{l}\text { Annual household expenditure (SZL) of other food products, food } \\
\text { group5(Oils, fats, sugar, and syrups) }\end{array}$ & $12,185.89$ & $21,036.05$ \\
\hline $\mathrm{P} 1$ & Annual price (SZL/Kg.) of food group 1 (Cereals, roots, and tubers) & 0.9335 & 4.2436 \\
\hline $\mathrm{P} 2$ & $\begin{array}{l}\text { Annual price (SZL/Kg.) of food group } 2 \text { (Vegetables, legumes and } \\
\text { nuts) }\end{array}$ & 0.6001 & 6.0199 \\
\hline P3 & Annual price (SZL/Kg.) of food group 3 (Fruits) & 0.3608 & 4.2391 \\
\hline P4 & $\begin{array}{l}\text { Annual price (SZL/Kg.) of food group } 4 \text { (Meat, fish, eggs and dairy } \\
\text { products) }\end{array}$ & 10.3260 & 103.5306 \\
\hline P5 & $\begin{array}{l}\text { Annual price (SZL/Kg.) of other food products, food group5(Oils, } \\
\text { fats, sugar and syrups) }\end{array}$ & 2.1566 & 31.7364 \\
\hline dumprod1 & Dummy variable $=1$ if hh produces Cereals and 0 otherwise. & 0.4480 & 0.4974 \\
\hline dumprod 2 & Dummy variable $=1$ if hh produces Vegetables and 0 otherwise. & 0.2167 & 0.4120 \\
\hline dumprod3 & Dummy variable $=1$ if hh produces Fruits and 0 otherwise. & 0.1075 & 0.3098 \\
\hline dumprod4 & Dummy variable $=1$ if hh produces Meat and 0 otherwise. & 0.5409 & 0.4984 \\
\hline dumprod5 & Dummy variable $=1$ if hh produces Others and 0 otherwise. & 0.1473 & 0.3545 \\
\hline
\end{tabular}

Source: Authors' calculations based on data from SHIES (2009/2010)
Table 5 Summary statistics of demographic variables by region

\begin{tabular}{lll}
\hline & Mean & Standard deviation \\
\hline Hhohho & & \\
Household size & 4.002 & 2.900 \\
Age of the household head & 43.791 & 15.293 \\
Head gender & 0.581 & 0.494 \\
Lubomb & & \\
Household size & 4.599 & 3.236 \\
Age of the household head & 45.229 & 14.773 \\
Head gender & 0.577 & 0.494 \\
Manzin & & \\
Household size & 4.383 & 3.321 \\
Age of the household head & 43.724 & 15.159 \\
Head gender & 0.561 & 0.490 \\
Shisel & & \\
Household size & 5.401 & 3.699 \\
Age of the household head & 49.427 & 18.019 \\
Head gender & 0.422 & 0.494 \\
\hline
\end{tabular}

Source: Authors' calculations based on data from SHIES (2009/2010) of low, medium, and high GHG emissions. ${ }^{15}$ The IFPRI projected prices are based on climate change projections that are also typically based on average projected changes in precipitation and temperature up to either 2050, 2070, or 2100. The paper (Nelson et al. 2010) presented the projections for the 2050 average. Based on IPCC's Special Report on Emissions Scenarios (SRES), climate change is given as a warming average for the period 2011 to 2030 compared to say 1980 to 1999 . Thus the estimate is not a series of changes in climate over time but discrete values of the average. This average change in temperature and precipitation was used $\mathrm{n}$ the IFPRI paper to model price changes due to climate change. The price changes used in the welfare analysis are based on projected changes in one food category - cereal. The IFPRI projected prices covered three commodities: maize,

\footnotetext{
$\overline{15}$ Three overall scenarios, under five climate scenarios, result in 15 perspectives on the future that encompass a wide range of plausible outcomes. Using the baseline scenario, they experimented with a variety of crop productivity enhancement simulations.
} 
Fig. 1 Percentage of households producing each of the commodity groups. Source: Authors' calculations based on data from SHIES $(2009 / 2010)$

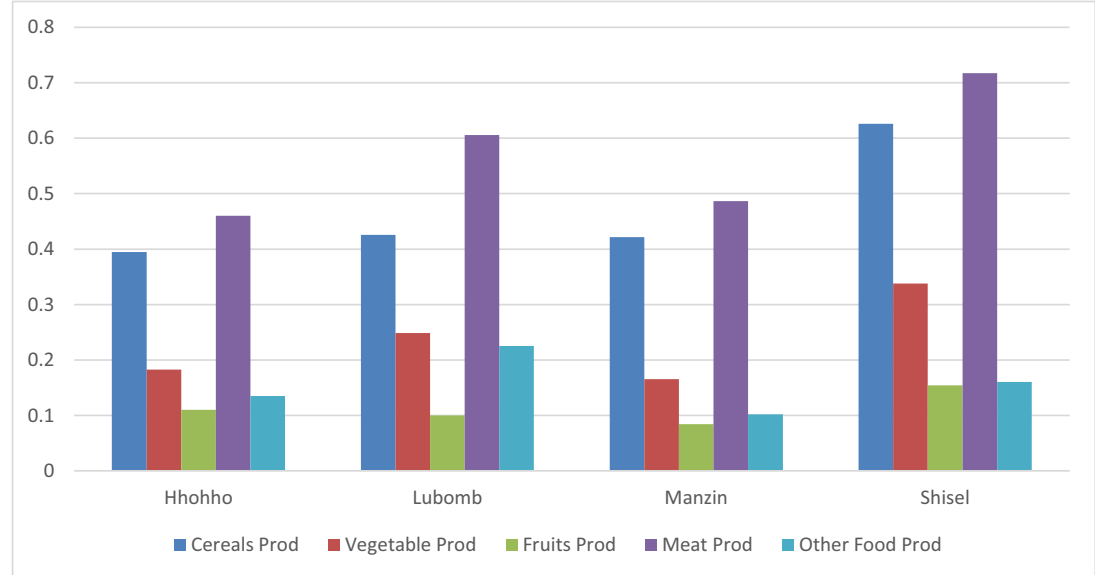

Source: Authors' calculations based on data from SHIES (2009/2010) rice, and wheat. These three commodities add up to about $58 \%$ of annual food expenditure in Swaziland.

The results of the first stage probit estimations can be found in Table 6 . In the first stage, we estimate the likelihood of choosing each of the food categories by a household. The dependent variables in these equations are dichotomous variables that take the value 1 if the household makes a purchase and zero otherwise. In addition to income (deciles) and food prices, the probit models also control for the effects of several household characteristics on the probability of consumption. Estimated coefficients on the income decile, household size, and region 2 (Hhohho) are positive and significant for all food groups and significant at $1 \%$ level. The income decile coefficient is highly significant at $1 \%$ level and positive, indicating that the higher the income level, the higher one's consumption level of each food group, especially the cereals, roots, and tubers category. The coefficient on the location variable indicates that rural households consume fewer meats and vegetables than urban households. The gender coefficient indicates that male-headed households consume less cereal and vegetables than female-headed households. Residents of the Manzini, Hhohho, and Shiselweni regions are significantly more likely to consume the food categories than residents of the Lubombo region (omitted to avoid perfect collinearity), which has lower crop yields. It is important to note that the first stage only serves to correct for potential censoring bias in the main parameters of interest (second stage), hence the lack of emphasis on the results.

\subsection{Second stage results}

Table 7 presents the second-stage parameter estimates of the censored AIDS model. The results show that all price and expenditure parameters and most of the parameters for the demographic variables are significant. All five inverse mills ratio coefficients are statistically significant, indicating the statistical necessity to account for the censoring of the commodities.

Since these coefficients do not lend themselves to a direct economic interpretation, we focus our discussion on the elasticity estimates instead. Table 8 presents expenditure shares and expenditure elasticities for the five food commodities, given at means. The results indicate that all the commodities are normal goods, consumption of which will increase with an increase in income. Overall, the results show price elasticities below 1.0 for cereals $(0.9560)$, vegetables, legumes and nuts (0.8368), and fruits (0.7984). This indicates that these food groups are relatively income inelastic. On the other hand, the expenditure elasticities for meats and dairy (1.0561) and the other food group (which includes sugars, fats, and oils) (1.1738) suggest that they are luxury goods.

Price elasticities quantify the responsiveness of quantity demanded to a change in prices. As illustrated in the approximation of the $\mathrm{CV}$ equation, they are an essential input to the formulation of tax or subsidy policies designed to mitigate consumer welfare loss spurred by adverse price changes. Uncompensated elasticities measure households' adjustment of quantities consumed as a result of a price change; as such, they reflect both income and substitution effects induced by the change in price. Compensated elasticities, on the other hand, measure only the substitution effect of a price change when consumers are compensated just enough to stay on their pre-price change utility level.

Uncompensated and compensated elasticities from the AIDS model, evaluated at the mean sample of the data, are reported in Table 9 in matrix form with rows and columns composed of the five food groups: (1) cereals, roots, and tubers, (2) vegetables, legumes, and nuts, (3) fruits, (4) meat, fish, eggs and dairy products and (5) other foods, respectively. A few observations are worthy of a brief discussion. First, all elasticities are less than unity in absolute value, indicating that the food groups are not very sensitive to changes in prices. 
Table 6 Probit model explaining the likelihood of consuming each of the food groups

\begin{tabular}{|c|c|c|c|c|c|}
\hline Variables & $\begin{array}{l}\text { (1) } \\
\text { Cereals }\end{array}$ & $\begin{array}{l}\text { (2) } \\
\text { Vegetables }\end{array}$ & $\begin{array}{l}\text { (3) } \\
\text { Fruits }\end{array}$ & $\begin{array}{l}\text { (4) } \\
\text { Meats }\end{array}$ & $\begin{array}{l}\text { (5) } \\
\text { Other }\end{array}$ \\
\hline Decile & $\begin{array}{l}0.2152 * * * \\
(0.0188)\end{array}$ & $\begin{array}{l}0.1017 * * * \\
(0.0113)\end{array}$ & $\begin{array}{l}0.1731 \text { *** } \\
(0.0103)\end{array}$ & $\begin{array}{l}0.1788^{* * * *} \\
(0.0134)\end{array}$ & $\begin{array}{l}0.0472 * * * * \\
(0.0113)\end{array}$ \\
\hline Head age & $\begin{array}{l}-0.0048^{*} \\
(0.0027)\end{array}$ & $\begin{array}{l}0.0007 \\
(0.0019)\end{array}$ & $\begin{array}{l}-0.0023 \\
(0.0017)\end{array}$ & $\begin{array}{l}-.0068^{* * *} \\
(0.0021)\end{array}$ & $\begin{array}{l}-0.0006 \\
(0.0019)\end{array}$ \\
\hline Head gender & $\begin{array}{l}-0.1657 * \\
(0.0892)\end{array}$ & $\begin{array}{l}-.1699 * * * \\
(0.0551)\end{array}$ & $\begin{array}{l}-0.0693 \\
(0.0481)\end{array}$ & $\begin{array}{l}0.0175 \\
(0.0653)\end{array}$ & $\begin{array}{l}-0.0792 \\
(0.0550)\end{array}$ \\
\hline Hhsize & $\begin{array}{l}0.1484 * * * \\
(0.0195)\end{array}$ & $\begin{array}{l}0.0768 * * * \\
(0.0108)\end{array}$ & $\begin{array}{l}0.0803 * * * \\
(0.0091)\end{array}$ & $\begin{array}{l}0.1196 * * * \\
(0.0131)\end{array}$ & $\begin{array}{l}0.0995 * * * \\
(0.0115)\end{array}$ \\
\hline Location & $\begin{array}{l}-0.0285 \\
(0.1273)\end{array}$ & $\begin{array}{l}-.2306^{* * * *} \\
(0.0728)\end{array}$ & $\begin{array}{l}-0.0508 \\
(0.0641)\end{array}$ & $\begin{array}{l}-.2514 * * * \\
(0.0907)\end{array}$ & $\begin{array}{l}-0.0520 \\
(0.0710)\end{array}$ \\
\hline Hhohho & $\begin{array}{l}0.0082 \\
(0.1141)\end{array}$ & $\begin{array}{l}0.2887 * * * \\
(0.0744)\end{array}$ & $\begin{array}{l}0.2896 \text { **** } \\
(0.0671)\end{array}$ & $\begin{array}{l}0.1325 \\
(0.0859)\end{array}$ & $\begin{array}{l}0.1393^{*} \\
(0.0739)\end{array}$ \\
\hline Manzini & $\begin{array}{l}0.2779 * * \\
(0.1282)\end{array}$ & $\begin{array}{l}0.1818^{* *} \\
(0.0744)\end{array}$ & $\begin{array}{l}0.3150 * * * \\
(0.0680)\end{array}$ & $\begin{array}{l}0.2685 * * * \\
(0.0900)\end{array}$ & $\begin{array}{l}0.1501 * * \\
(0.0753)\end{array}$ \\
\hline Shiselweni & $\begin{array}{l}-0.0843 \\
(0.1324)\end{array}$ & $\begin{array}{l}0.2453 * * * \\
(0.0887)\end{array}$ & $\begin{array}{l}0.4274 * * * \\
(0.0797)\end{array}$ & $\begin{array}{l}0.2458^{* *} \\
(0.1028)\end{array}$ & $\begin{array}{l}0.4140^{* * * *} \\
(0.0958)\end{array}$ \\
\hline dumprod1 & $\begin{array}{l}-0.2370^{* * *} \\
(0.1144)\end{array}$ & $\begin{array}{l}0.0239 \\
(0.0718)\end{array}$ & $\begin{array}{l}-0.1128^{*} \\
(0.0644)\end{array}$ & $\begin{array}{c}-0.0996 \\
(0.0838)\end{array}$ & $\begin{array}{l}0.1686^{* *} \\
(0.0734)\end{array}$ \\
\hline dumprod2 & $\begin{array}{l}-0.0553 \\
(0.1145)\end{array}$ & $\begin{array}{l}0.1132 \\
(0.0758)\end{array}$ & $\begin{array}{l}0.0078 \\
(0.0655)\end{array}$ & $\begin{array}{l}-0.0746 \\
(0.0853)\end{array}$ & $\begin{array}{l}0.0610 \\
(0.0799)\end{array}$ \\
\hline dumprod3 & $\begin{array}{l}0.2629^{*} \\
(0.1523)\end{array}$ & $\begin{array}{l}0.2479 * * \\
(0.0974)\end{array}$ & $\begin{array}{l}-0.0918 \\
(0.0812)\end{array}$ & $\begin{array}{l}0.0338 \\
(0.1054)\end{array}$ & $\begin{array}{l}0.0499 \\
(0.1010)\end{array}$ \\
\hline dumprod 4 & $\begin{array}{l}-0.1974 * \\
(0.1093)\end{array}$ & $\begin{array}{l}-0.0186 \\
(0.0674)\end{array}$ & $\begin{array}{l}-0.0233 \\
(0.0601)\end{array}$ & $\begin{array}{l}-0.2388 \\
(0.0823)\end{array}$ & $\begin{array}{l}-0.0293 \\
(0.0665)\end{array}$ \\
\hline dumprod5 & $\begin{array}{l}-0.0295 \\
(0.1320)\end{array}$ & $\begin{array}{l}-0.2066^{* *} \\
(0.0850)\end{array}$ & $\begin{array}{l}0.0865 \\
(0.0753)\end{array}$ & $\begin{array}{l}0.1031 \\
(0.0994)\end{array}$ & $\begin{array}{l}0.0247 \\
(0.0926)\end{array}$ \\
\hline Constant & $\begin{array}{l}0.2322 \\
(0.2226)\end{array}$ & $\begin{array}{l}-0.0955 \\
(0.1434)\end{array}$ & $\begin{array}{l}-1.3857 * * * \\
(0.1310)\end{array}$ & $\begin{array}{l}-0.0290 \\
(0.1680)\end{array}$ & $\begin{array}{l}0.0455 \\
(0.1453)\end{array}$ \\
\hline Observations & 3143 & 3143 & 3143 & 3143 & 3143 \\
\hline
\end{tabular}

Robust standard errors in parentheses; $* * *$ for $\mathrm{p}$ value $<0.01 \%$, ** for $\mathrm{p}$ value $<0.05$, and $*$ for $p$ value $<0.1$

Second, all compensated and uncompensated own-price elasticities of consumed commodities are negative and statistically different from zero as expected and consistent with the law of demand. Third, the estimated income effect is significant given the sizable differences between the compensated and uncompensated elasticities in general. For example, a $1 \%$ increase in the price of cereals leads to a $0.1386 \%$ decline in the demand for meats (uncompensated elasticity) when the income effect is considered. With no income effect, the same price change leads to a $0.1973 \%$ increase in the demand for meats due to a pure substitution effect to the relatively cheaper commodity. The size of the income effect is further evidenced by the fact that there are several gross complements (uncompensated elasticities) but net substitutes (compensated elasticities). We now turn to the welfare analysis to examine how consumers would fare if the projected price increases due to climate change were to materialize.

\subsection{Welfare analysis}

To gauge the price effects of climate change on household welfare, we used the same scenarios from IFPRI's food price projections to the year 2050 (Nelson et al. 2010). The use of scenarios is essential for climate change modeling because of the uncertainty about future economic development and human activities. The IFPRI food price projections were developed based on the original climate scenarios used in the SRES of the third IPCC assessment. ${ }^{16}$ From the SRES, individual scenarios are grouped into families depending on assumptions around future population, GDP, and GDP per capita. For the IFPRI price projections and, consequently, welfare estimates in this paper, the scenarios A1B, A2, and B1 form the basis for the optimistic and pessimistic price projections. The population, GDP, and GDP per capita estimates from the SRES were updated by IFPRI to capture the 2010-2050 period (see Table A2.1 in Nelson et al. 2010).

As done in the IFPRI study, we consider three cases: the baseline or most likely case, an optimistic case with high income and low population growth and pessimistic case

\footnotetext{
${ }^{16}$ See www.ipcc.ch/ipccreports/sres/emission/index.php?idp=0. The SRES scenarios are "baseline" (or "reference") scenarios, which means that they do not take into account any current or future measures to limit greenhouse gas (GHG) emissions (e.g., the Kyoto Protocol to the United Nations Framework Convention on Climate Change). The IPCC did not state that any of the SRES scenarios were more likely to occur than others. Therefore, none of the SRES scenarios stand for a "best guess" of future emissions.
} 
Table 7 AIDS model estimates (Eq. 5)

Food groups

\begin{tabular}{|c|c|c|c|c|c|}
\hline Variables & Cereals, roots and tubers & Vegetables, legumes and nuts & Fruits & Meat, eggs and dairy products & Other \\
\hline$\gamma$ (prices) & $0.1022 * * *$ & & & & \\
\hline Cereals & $(0.0039)$ & & & & \\
\hline \multirow[t]{2}{*}{ Vegetables } & $-0.0323 * * *$ & $0.0369 * * *$ & & & \\
\hline & $(0.0021)$ & $(0.0027)$ & & & \\
\hline \multirow[t]{2}{*}{ Fruits } & $-0.0153 * * *$ & $-0.0065 * * *$ & $0.0151 * * *$ & & \\
\hline & $(0.0018)$ & $(0.0015)$ & $(0.0018)$ & & \\
\hline \multirow[t]{2}{*}{ Meat } & $-0.0553 * * *$ & $-0.0043 * *$ & 0.0032 & $0.0739 * * *$ & \\
\hline & $(0.0026)$ & $(0.0021)$ & $(0.0017)$ & $(0.0030)$ & \\
\hline \multirow[t]{2}{*}{ Other } & $-0.0294 * * *$ & $-0.0110^{* * *}$ & $-0.0135 * * *$ & 0.0009 & $0.0339 * * *$ \\
\hline & $(0.0023)$ & $(0.0021)$ & $(0.0016)$ & $(0.0023)$ & $(0.0035)$ \\
\hline \multirow[t]{2}{*}{$\alpha$} & $0.6062 * * *$ & $0.4569 * * *$ & $0.3651 * * *$ & -0.0301 & $0.4906^{* * *}$ \\
\hline & $(0.0316)$ & $(0.0339)$ & $(0.0261)$ & $(0.0374)$ & $(0.0436)$ \\
\hline \multirow[t]{2}{*}{$\mathrm{b}$} & $-0.0172 * * *$ & $-0.0263 * * *$ & $-0.01474 * * *$ & $0.0241 * * *$ & $-0.0382 * * *$ \\
\hline & $(0.0026)$ & $(0.0022)$ & $(0.00177)$ & $(0.0029)$ & $(0.0022)$ \\
\hline \multirow[t]{2}{*}{ s1 } & -0.0032 & $-0.0257 * * *$ & 0.0023 & $0.0391 * * *$ & -0.0086 \\
\hline & $(0.0061)$ & $(0.0053)$ & $(0.0042)$ & $(0.0067)$ & $(0.0055)$ \\
\hline \multirow[t]{2}{*}{ s2 } & -0.0001 & -0.0001 & 0.0001 & 0.0001 & $0.0006^{* * *}$ \\
\hline & $(0.0002)$ & $(0.0002)$ & $(0.0001)$ & $(0.0003)$ & $(0.0002)$ \\
\hline \multirow[t]{2}{*}{ s3 } & $0.0045 * * *$ & $0.0042 * * *$ & $-0.0047 * * *$ & $-0.0063 * * *$ & $0.0066^{* * *}$ \\
\hline & $(0.0011)$ & $(0.0010)$ & $(0.0008)$ & $(0.0013)$ & $(0.0015)$ \\
\hline \multirow[t]{2}{*}{ s4 } & $0.0333 * * *$ & $-0.0260 * * *$ & 0.0078 & $-0.0360 * * *$ & $0.0244 * * *$ \\
\hline & $(0.0082)$ & $(0.0079)$ & $(0.0059)$ & $(0.0093)$ & $(0.0077)$ \\
\hline \multirow[t]{2}{*}{ s5 } & $-0.0509 * * *$ & $0.0394 * * *$ & $0.0186^{* * *}$ & 0.0095 & -0.0031 \\
\hline & $(0.0088)$ & $(0.0083)$ & $(0.0065)$ & $(0.0099)$ & $(0.0084)$ \\
\hline \multirow[t]{2}{*}{ s6 } & $-0.0462 * * *$ & $0.0286^{* * *}$ & 0.0074 & 0.0090 & 0.0050 \\
\hline & $(0.0089)$ & $(0.0081)$ & $(0.0066)$ & $(0.0100)$ & $(0.0086)$ \\
\hline \multirow[t]{2}{*}{ s7 } & $-0.0456^{* * *}$ & $0.0473 * * *$ & $0.0156 * *$ & $-0.0264 * *$ & $0.0275 * *$ \\
\hline & $(0.0105)$ & $(0.0094)$ & $(0.0078)$ & $(0.0118)$ & $(0.0115)$ \\
\hline \multirow[t]{2}{*}{ s8 } & $-0.0181 * *$ & $0.0049 * *$ & 0.0049 & -0.0134 & $0.0368 * * *$ \\
\hline & $(0.0086)$ & $(0.0072)$ & $(0.0059)$ & $(0.0095)$ & $(0.0082)$ \\
\hline \multirow[t]{2}{*}{ s9 } & $-0.0154^{*}$ & 0.0027 & -0.0095 & 0.0069 & $0.0158 * *$ \\
\hline & $(0.0085)$ & $(0.0070)$ & $(0.0059)$ & $(0.0094)$ & $(0.0070)$ \\
\hline \multirow[t]{2}{*}{ s10 } & $-0.0267 * *$ & $0.0345 * * *$ & -0.0032 & 0.0156 & -0.0063 \\
\hline & $(0.0105)$ & $(0.0086)$ & $(0.0073)$ & $(0.0117)$ & $(0.0085)$ \\
\hline \multirow[t]{2}{*}{ s11 } & -0.0018 & 0.0064 & 0.0074 & -0.0133 & $0.0125^{*}$ \\
\hline & $(0.0077)$ & $(0.0064)$ & $(0.0052)$ & $(0.0085)$ & $(0.0069)$ \\
\hline \multirow[t]{2}{*}{$\mathrm{s} 12$} & 0.0023 & -0.0100 & $0.0137 * *$ & -0.0042 & -0.0029 \\
\hline & $(0.0098)$ & $(0.0085)$ & $(0.0068)$ & $(0.0108)$ & $(0.0079)$ \\
\hline \multirow[t]{2}{*}{ theta_d1 } & $0.1994 * * *$ & & & & \\
\hline & $(0.0373)$ & & & & \\
\hline \multirow[t]{2}{*}{ theta_d2 } & & $0.2398 * * *$ & & & \\
\hline & & $(0.0319)$ & & & \\
\hline \multirow{2}{*}{\multicolumn{2}{|c|}{ theta_d3 }} & & $-0.1144 * * *$ & & \\
\hline & & & $(0.0096)$ & & \\
\hline \multirow{2}{*}{\multicolumn{2}{|c|}{ theta_d4 }} & & & $0.2520 * * *$ & \\
\hline & & & & $(0.0309)$ & \\
\hline theta_d5 & & & & & $0.2606 * * *$ \\
\hline & & & & & $(0.0534)$ \\
\hline
\end{tabular}

Notes: Robust standard errors in parentheses; *** for $\mathrm{p}$ value $<0.01 \%$, ** for $\mathrm{p}$ value $<0.05$, and $*$ for $\mathrm{p}$ value $<0.1$. The sij's are the coefficients on the demographic variables. Included, in this order: head age, head gender, hhsize, location $(1=$ rural), region1, region2, region 3 , dumprod1, dumprod2, dumprod3, dumprod4, dumprod5. The theta_dj are the IMR coefficients. Once for each category. They are highly significant indicating the importance of accounting for the zero observations 
Table 8 Expenditure elasticities and expenditure shares for purchased food commodities
Table 9 Uncompensated and compensated own price elasticities for purchased commodities

\begin{tabular}{lll}
\hline Variable & Expenditure share & Expenditure elasticity \\
\hline Cereals/ roots and tubers & $\mathbf{0 . 3 5 7 2}$ & $0.9560^{* * *}$ \\
Vegetables, legumes and nuts & 0.1153 & $(0.0100)$ \\
& & $0.8368 * * *$ \\
Fruits & 0.0420 & $(0.0190)$ \\
Meat, fish, eggs and dairy products & & $0.7984 * * *$ \\
& $\mathbf{0 . 3 5 1 4}$ & $(0.0319)$ \\
Other food products & & $\mathbf{1 . 0 5 6 1 * * *}$ \\
& 0.1341 & $(0.0102)$ \\
& & $\mathbf{1 . 1 7 3 8 * * *}$ \\
\hline
\end{tabular}

Notes: $* * *$ for $\mathrm{p}$ value $<0.01 \%$, ** for $p$ value $<0.05$, and $*$ for $\mathrm{p}$ value $<0.1$. We follow standard practice (see e.g. Bilgic and Yen 2013; Sam 2010b) and report bootstrapped standard errors (in parentheses) instead of secondstage standard errors due to the use of a predicted regressor (inverse Mills ratio) and the predicted probability of consumption

\begin{tabular}{|c|c|c|c|c|c|}
\hline Price of food group & $\begin{array}{l}\text { Cereals, } \\
\text { roots and } \\
\text { tubers }\end{array}$ & $\begin{array}{l}\text { vegetables, } \\
\text { legumes and } \\
\text { nuts }\end{array}$ & Fruits & $\begin{array}{l}\text { Meat, fish, eggs } \\
\text { and dairy products }\end{array}$ & $\begin{array}{l}\text { Other food } \\
\text { products }\end{array}$ \\
\hline \multicolumn{6}{|c|}{ Uncompensated elasticities } \\
\hline $\begin{array}{l}\text { Cereals, roots and } \\
\text { tubers }\end{array}$ & $\begin{array}{l}-0.7135^{* * *} \\
(0.0111)\end{array}$ & $\begin{array}{l}-0.0642 * * * \\
(0.0049)\end{array}$ & $\begin{array}{l}-0.0297 * * * \\
(0.0046)\end{array}$ & $\begin{array}{l}-0.1386^{* * *} \\
(0.0083)\end{array}$ & $\begin{array}{l}-0.0099 \\
(0.0122)\end{array}$ \\
\hline $\begin{array}{l}\text { Vegetables, } \\
\text { legumes and } \\
\text { nuts }\end{array}$ & $\begin{array}{l}-0.1094 * * * \\
(0.0128)\end{array}$ & $\begin{array}{l}-0.7017^{* * *} \\
(0.0133)\end{array}$ & $\begin{array}{l}-0.0054 \\
(0.0083)\end{array}$ & $\begin{array}{l}-0.0151 \\
(0.0132)\end{array}$ & $\begin{array}{l}-0.0052 \\
(0.0165)\end{array}$ \\
\hline Fruits & $\begin{array}{l}-0.0962 * * * \\
(0.0259)\end{array}$ & $\begin{array}{l}-0.0038 \\
(0.0179)\end{array}$ & $\begin{array}{l}-0.7507 * * * \\
(0.0232)\end{array}$ & $\begin{array}{l}0.0575 * * \\
(0.0254)\end{array}$ & $\begin{array}{l}-0.0053 \\
(0.0326)\end{array}$ \\
\hline $\begin{array}{l}\text { Meat, fish, eggs } \\
\text { and dairy } \\
\text { products }\end{array}$ & $\begin{array}{l}-0.1602 * * * \\
(0.0075)\end{array}$ & $\begin{array}{l}-0.0337^{* * *} \\
(0.0043)\end{array}$ & $\begin{array}{l}-0.0046 \\
(0.0035)\end{array}$ & $\begin{array}{l}-0.8316^{* * *} \\
(0.0109)\end{array}$ & $\begin{array}{l}-0.0260 * * * \\
(0.0093)\end{array}$ \\
\hline $\begin{array}{l}\text { Other food } \\
\text { products }\end{array}$ & $\begin{array}{l}-0.2191 * * * \\
(0.0256)\end{array}$ & $\begin{array}{l}0.0041 \\
(0.0123)\end{array}$ & $\begin{array}{l}0.0177 \\
(0.0122)\end{array}$ & $\begin{array}{l}-0.0771^{* * *} \\
(0.0199)\end{array}$ & $\begin{array}{l}-0.8994 * * * \\
(0.0504)\end{array}$ \\
\hline \multicolumn{6}{|c|}{ Compensated elasticities } \\
\hline $\begin{array}{l}\text { Cereals, roots and } \\
\text { tubers }\end{array}$ & $\begin{array}{l}-0.3720^{* * *} \\
(0.0115)\end{array}$ & $\begin{array}{l}0.0460 * * * \\
(0.0051)\end{array}$ & $\begin{array}{l}0.0105 * * \\
(0.0047)\end{array}$ & $\begin{array}{l}0.1973 * * * \\
(0.0081)\end{array}$ & $\begin{array}{l}0.1182 * * * \\
(0.0116)\end{array}$ \\
\hline $\begin{array}{l}\text { Vegetables, } \\
\text { legumes and } \\
\text { nuts }\end{array}$ & $\begin{array}{l}0.1895 * * * \\
(0.0125)\end{array}$ & $\begin{array}{l}-0.6052 * * * \\
(0.0140)\end{array}$ & $\begin{array}{l}0.0297 * * * \\
(0.0086)\end{array}$ & $\begin{array}{l}0.2789 * * * \\
(0.0119)\end{array}$ & $\begin{array}{l}0.1070 * * * \\
(0.0155)\end{array}$ \\
\hline Fruits & $\begin{array}{l}0.1890 * * * \\
(0.0246)\end{array}$ & $\begin{array}{l}0.0882 * * * \\
(0.0185)\end{array}$ & $\begin{array}{l}-0.7171^{* * * *} \\
(0.0233)\end{array}$ & $\begin{array}{l}0.3381 * * * \\
(0.0210)\end{array}$ & $\begin{array}{l}0.1017 * * * \\
(0.0319)\end{array}$ \\
\hline $\begin{array}{l}\text { Meat, fish, eggs } \\
\text { and dairy } \\
\text { products }\end{array}$ & $\begin{array}{l}0.2170 * * * \\
(0.0075)\end{array}$ & $\begin{array}{l}0.0881 * * * \\
(0.0043)\end{array}$ & $\begin{array}{l}0.0398 * * * \\
(0.0039)\end{array}$ & $\begin{array}{l}-0.4605 * * * \\
(0.0104)\end{array}$ & $\begin{array}{l}0.1156^{* * * *} \\
(0.0089)\end{array}$ \\
\hline $\begin{array}{l}\text { Other food } \\
\text { products }\end{array}$ & $\begin{array}{l}0.2002 * * * \\
(0.0277)\end{array}$ & $\begin{array}{l}0.1395 * * * \\
(0.0134)\end{array}$ & $\begin{array}{l}0.0670 * * * \\
(0.0125)\end{array}$ & $\begin{array}{l}0.3354 * * * \\
(0.0219)\end{array}$ & $\begin{array}{l}-0.7420 \text { *** } \\
(0.0483)\end{array}$ \\
\hline
\end{tabular}

Notes: $* * *$ for $\mathrm{p}$ value $<0.01 \%$, ** for $\mathrm{p}$ value $<0.05$, and $*$ for $\mathrm{p}$ value $<0.1$. We follow standard practice (see e.g., Bilgic and Yen 2013; Sam 2010b) and report bootstrapped standard errors (in parentheses) instead of secondstage standard errors due to the use of a predicted regressor (inverse Mills ratio) and the predicted probability of consumption 
with low income and high population growth rate. We use data from Table 2.2 of Nelson et al. (2010) for these three scenarios to come up with projected prices increases that reflect consumption patterns in Swaziland for the cereal group only. ${ }^{17}$ Cereal prices are expected to rise by $70.14 \%, 53.85 \%$, and $82.1 \%$, respectively in the baseline (most likely), optimistic and pessimistic cases by 2050 , relative to 2010 baseline prices.

We combine the projected price increases mentioned above with the budget shares of the five commodity groups and their compensated price elasticities to estimate the first and secondorder components of the compensating variation (Eq. 2). Table 10 presents the results of the welfare analysis for the three scenarios based on changes in the prices of maize, wheat, and rice (cereal group).

Two key observations emerge from the welfare estimation. First, the proportionate increase in income required to maintain pre-price change utilities is roughly the same across the income distribution as well as between urban and rural residents (unlike Friedman and Levinsohn (2002)). The estimated compensation variation figures indicate that climate spurredincreases in cereal prices are expected to lead to a significant worsening of well-being among Swazi consumers, income transfers of between 17.48 and $25.44 \%$ of pre-change expenditure are needed to avoid welfare losses depending on the price projection scenario. Swazi households are likely to experience even higher welfare losses due to increases in the prices of the other food categories, which for this analysis are held constant. Meat and dairy prices are likely to rise due to drier climate conditions and therefore reduced pasture for meat production.

Second, compared to the baseline (current) poverty rates, we find that the projected increases in cereal prices will result in a significant rise in poverty in the absence of an intervention to mitigate the consequences of the price increases. Per the survey data, many Swazi households live under SZL461 (about $\$ 63$ based on the exchange rate at the time of the survey) per adult per month. This translates into a $100 \%$ poverty rate for $63 \%$ for all households that are in the 1st to the 6th household income deciles. The poverty rate declines to $28 \%$ at the 7th decile, and it is zero from the 8th to 10th decile. A $100 \%$ extreme poverty rate (below SZL215.00 per adult per month) is observed for the two lowest deciles, and it declines to $87.4 \%$ for households in the third decile and zeroes for all other deciles. $63 \%$ (28\%) of rural residents are classified as poor (extremely poor), with $25 \%$ (4\%) of urban residents classified as such.

\footnotetext{
${ }^{17}$ The IFPRI projected prices are not country specific. We therefore adapt the projections to broad consumption patterns in Swaziland by weighting the projected price increases for Maize, Rice and Wheat with their expenditure percentages from our survey data. Unfortunately, the projected price changes did not include the other food categories considered in the analysis. They are therefore set to zero for the purpose of the welfare analysis.
}

With the estimated compensating variation figures, we calculated the new poverty rates that would prevail if the projected price increases were to materialize based on the current national poverty (SZL 462 a day per adult) and extreme poverty (SZL 125) levels. Doing so, we find a drastic increase in both poverty measures across the income distribution with $94.6 \%$ of households in decile 7 (compared to $28 \%$ with no price change) and $29.1 \%$ of households in decile 8 (compared to $0 \%$ with no price change) classified as "poor" in the most likely scenario. Extreme poverty is expected to increase similarly, going from zero to $84 \%$ and $23 \%$ for households in the fourth- and fifth-income deciles, respectively. Table 11 further summarizes the estimated welfare effects. While urban households are expected to experience faster growth in poverty compared to rural households (between a 33 and $51 \%$ growth in the poverty rate), poverty rates for rural households are expected to increase to alarming levels (between 70 and $74 \%$ ). Extreme poverty is expected to double in urban areas though it will remain a small fraction compared to extreme poverty in rural areas $(8.59 \%$ vs. $40.78 \%$ in the most likely scenario). The combination of the results in the urban and rural areas indicates that climate change is expected to have severe consequences for the well-being of households in developing countries with poorer rural households bearing the brunt of it.

\section{Discussion}

Our results show that Swazi households, especially those living in rural areas, could experience a significant deterioration in living standards if the IFPRI-projected climate scenarios were to materialize. Absent any intervention to mitigate the effect of food price increases, poverty rates are expected to increase by ten percentage points, up from 25 and 63\%, respectively, in urban and rural areas. Likewise, extreme poverty is expected to double in urban areas but affect a relatively small fraction of residents (from 4 to nearly 9\%) in the most likely scenario. In rural areas, extreme poverty is expected to rise from 28 to $41 \%$ in the most likely scenario. Besides the documented negative effect on poverty, a significant increase in food prices has the potential to generate violence and social unrest, as evidenced by Bellemare (2015). Climate change could also accentuate the volatility of agricultural production and prices, leading to increased risks for producers, consumers, and governments alike (Li et al. 2017; Sam 2010a).

As mentioned above, a spate of papers have studied the links between food prices and poverty. Three of these are closely related to ours. Dessus et al. (2008) conclude that a growth rate of gross domestic product (GDP) between 0.2 and $3 \%$ is required to offset the effect of increased food prices on urban poverty. Simulations by Hertel et al. (2010) indicate that a rapid rise in global temperatures, combined with high 
Table 10 Analysis of welfare effects due to an increase in cereal prices by household income decile

\begin{tabular}{llllllllllllll}
\hline & Decile & 1 & 2 & 3 & 4 & 5 & 6 & 7 & 8 & 9 & 10 \\
\hline \multirow{5}{*}{ Most likely } & Baseline poverty rate & 1 & 1 & 1 & 1 & 1 & 1 & 0.28 & 0 & 0 & 0 \\
& Baseline extreme poverty rate & 1 & 1 & 0.86 & 0 & 0 & 0 & 0 & 0 & 0 & 0 \\
& Compensating variation & 0.2128 & 0.2123 & 0.2304 & 0.2255 & 0.2237 & 0.2170 & 0.2228 & 0.2294 & 0.2245 & 0.2172 \\
& New poverty rate & 1 & 1 & 1 & 1 & 1 & 1 & 0.9461 & 0.2914 & 0 & 0 \\
& New extreme poverty rate & 1 & 1 & 1 & 0.8450 & 0.2281 & 0.0115 & 0.0084 & 0 & 0 & 0 \\
Pessimistic & Compensating variation & 0.1684 & 0.1680 & 0.1822 & 0.1783 & 0.1766 & 0.1713 & 0.1757 & 0.1810 & 0.1771 & 0.1714 \\
& New poverty rate & 1 & 1 & 1 & 1 & 1 & 1 & 0.8989 & 0.1285 & 0 & 0 \\
& New extreme poverty rate & 1 & 1 & 1 & 0.6556 & 0.0953 & 0 & 0 & 0 & 0 \\
& Compensating variation & 0.2430 & 0.2422 & 0.2632 & 0.2576 & 0.2558 & 0.2483 & 0.2550 & 0.2626 & 0.2569 & 0.2485 \\
& New poverty rate & 1 & 1 & 1 & 1 & 1 & 1 & 0.9570 & 0.4336 & 0.0116 & 0 \\
& New extreme poverty rate & 1 & 1 & 1 & 0.8901 & 0.3807 & 0.0234 & 0.0164 & 0.0034 & 0 \\
\hline
\end{tabular}

sensitivity of crops to heat and a low level of $\mathrm{CO}_{2}$ fertilization effect could result in as much as a $60 \%$ increase in prices by 2030 for major cereal crops. Such price increases are expected to raise the poverty rate by between 20 and $50 \%$ among nonagricultural households in some SSA countries. The estimated impacts on poverty take into account both the adverse change in the cost of living, which primarily affects urban wage earners, as well as a positive change in incomes (higher food prices due to reduced production and inelasticity of food demand) that mostly accrue to rural farmers. Similarly, simulations by Seaman et al. (2014) indicate that a 50\% drop in agricultural output and increase in food prices will lead to a significant increase in the number of people below the poverty line in Salima, Malawi, and a substantial drop in disposable income in the Northern Border Upland Cereal and Livestock Zone in Namibia among the poor and very poor, potentially leading to migration from rural to urban areas.

Unlike our paper, Dessus et al. (2008) did not focus on the impact of climate change, and the other two papers use simulation methods to generate their results. Instead, we adopt an econometric approach based on a popular microeconometric food demand model (AIDS) to study the impact of climate change on poverty at the household level. Despite the difference in analytical approaches, our results are broadly consistent with the findings of these papers: climate change spurred shocks to food prices could have debilitating consequences on the welfare of many households in SSA.

It should be stressed that our methodology does not fully capture the effects of increasing food prices due to climate change on food consumption. First, higher food prices generate a beneficial income effect for rural households whose income primarily emanates from agriculture (Dessus et al. 2008). That said, a large proportion-a majority in some countries-of food producers are net food buyers (Barrett and Lentz 2010; Jayne et al. 1999), hence will be adversely impacted by higher food prices without an attendant increase in income. The trend toward more urbanization in SSA is likely to magnify the household welfare losses discussed above. Second, increases in agricultural commodity prices could trigger a positive wage response that dampens the negative spending-related effect of the price increase (Hertel and Rosch 2010; Ravallion 1990). However, Banerjee (2007)
Table 11 Analysis of welfare effects due to an increase in cereal prices for rural and urban households

\begin{tabular}{lllll}
\hline & & Most likely & Optimistic & Pessimistic \\
\hline \multirow{3}{*}{ Urban } & Compensating variation & 0.2224 & 0.1755 & 0.2544 \\
& Baseline poverty rate & 0.2534 & 0.2534 & 0.2534 \\
& New poverty rate & 0.3589 & 0.3360 & 0.3833 \\
& Baseline extreme poverty rate & 0.0408 & 0.0408 & 0.0408 \\
& New extreme poverty rate & 0.0859 & 0.0740 & 0.0952 \\
& Compensating variation & 0.2214 & 0.1748 & 0.2531 \\
& Baseline poverty rate & 0.6314 & 0.6314 & 0.6314 \\
& New poverty rate & 0.7312 & 0.7071 & 0.7473 \\
& Baseline extreme poverty rate & 0.2815 & 0.2815 & 0.2815 \\
& New extreme poverty rate & 0.4078 & 0.3705 & 0.4319 \\
\hline
\end{tabular}


notes that such a positive wage response is not likely to materialize; instead, climate change could reduce wages for workers, creating a "double-whammy" spending and income effect. Finally, our welfare analysis rests on simulated changes in the prices of cereals only; further empirical research is needed to shed more light on the comprehensive effects of climate change on household welfare.

\section{Conclusion}

Climate change has become a subject of serious concern in Africa because of its potentially devastating effect on agriculture, the primary source of food production in the region. Our empirical estimates, based on household survey data from Swaziland, suggest that there is reason to be alarmed about its effects on poverty in SSA countries. Policy-wise, several actions can be taken to minimize the effects of climate change on household welfare. For example, international aid agencies and/or SSA governments could incentivize the adoption of climate resilient techniques and sustainable food security by training farmers on climate smart agricultural practices and providing subsidies to purchase inputs that tare are better suited for extreme weather patterns such as heat or drought resistant seeds to boost agricultural productivity (Onyutha 2019). Such policies should be coupled with better integration of rural food markets to regional and national markets. Doing so could motivate rural producers to increase food production, which in turn should minimize food price inflation. Households are also likely to adapt to the changing climate by diversifying income generating activities (Diiro and Sam 2015). Finally, SSA governments could keep price increases in check by reducing tariffs and other taxes on staple foods such as maize. Together, these policies could substantially mitigate the adverse effects of climate change on food prices and household welfare.

\section{Compliance with ethical standards}

Conflict of interest The authors whose names are listed in this manuscript certify that they have NO affiliations with or involvement in any organization or entity with any financial interest (such as honoraria; educational grants; participation in speakers' bureaus; membership, employment, consultancies, stock ownership, or other equity interest; and expert testimony or patent-licensing arrangements), or non-financial interest (such as personal or professional relationships, affiliations, knowledge or beliefs) in the subject matter or materials discussed in this manuscript.

Open Access This article is licensed under a Creative Commons Attribution 4.0 International License, which permits use, sharing, adaptation, distribution and reproduction in any medium or format, as long as you give appropriate credit to the original author(s) and the source, provide a link to the Creative Commons licence, and indicate if changes were made. The images or other third party material in this article are included in the article's Creative Commons licence, unless indicated otherwise in a credit line to the material. If material is not included in the article's
Creative Commons licence and your intended use is not permitted by statutory regulation or exceeds the permitted use, you will need to obtain permission directly from the copyright holder. To view a copy of this licence, visit http://creativecommons.org/licenses/by/4.0/.

\section{References}

Abdulai, A. (2002). Household demand for food in Switzerland. A quadratic almost ideal demand system. Swiss Society of Economics and Statistics, 138(1), 1-18 Available at https://www.researchgate.net/ profile/Awudu_Abdulai/publication. Accessed on 19/04/2015.

Abidoye, B.O., and Odusola, A.F., 2015. Climate change and economic growth in Africa: An econometric analysis. Journal of African Economies, p.eju033.

Agbola, F. W. (2003). Estimation of food demand patterns in South Africa based on a survey of households. Journal of Agricultural and Applied Economics, 35(1379-2016-113556), 663-670.

Baiphethi, M. N., \& Jacobs, P. T. (2009). The contribution of subsistence farming to food security in South Africa. Agrekon, 48(4), 459-482.

Banerjee, L. (2007). Effect of flood on agricultural wages in Bangladesh: An empirical analysis. World Development, 35(11), 1989-2009.

Barrett, C.B. and Lentz, E.C., 2010. Food insecurity. In Oxford Research Encyclopedia of International Studies.

Bellemare, M. F. (2015). Rising food prices, food price volatility, and social unrest. American Journal of Agricultural Economics, 97(1), $1-21$.

Bilgic, A., \& Yen, S. T. (2013). Household food demand in Turkey: A two-step demand system approach. Food Policy, 43, 267-277.

Brinkman, H. J., De Pee, S., Sanogo, I., Subran, L., \& Bloem, M. W. (2010). High food prices and the global financial crisis have reduced access to nutritious food and worsened nutritional status and health. The Journal of Nutrition, 140(1), 153S-161S.

Burki, S.J., Perry, G.E., de la Torre, A., Freire, M., and Huertas, M., 2012. Swaziland-reducing poverty through shared growth: summary report. Available at http://agris.fao.org/agris-search/search.do? recordID=US2012400099. Accessed on 20/01/2016.

Carter, M. R., \& Lybbert, T. J. (2012). Consumption versus asset smoothing: Testing the implications of poverty trap theory in Burkina Faso. Journal of Development Economics, 99, 255-264.

Carter, M. R., Little, P. D., Mogues, T., \& Negatu, W. (2007). Poverty traps and natural disasters in Ethiopia and Honduras. World Development, 35, 835-856.

Central Statistics Office. 2011. Poverty in a decade of slow economic growth: Swaziland in the 2000's. Available at http://www. trademarksa.org/news/poverty-decade-slow-economic-growthswaziland-2000-s. Accessed on 19/04/2015.

Centre for Economic Policy Research., 2010. Food prices and rural poverty. CEPR. http://documents.worldbank.org/curated/en/ $612501468154488885 / \mathrm{p} \mathrm{d} \mathrm{f/}$ 666770PUB00PUB0Prices0Rural0Poverty.pdf

Chang, C. H., Hooker, N. H., Jones, E., \& Sam, A. (2011). Organic and conventional milk purchase behaviors in Central Ohio. Agribusiness, 27(3), 311-326.

Deaton, A., \& Muellbauer, J. (1980). Economics and consumer behaviour. New York: Cambridge University Press.

Demeke, M. and Rashid, S., 2012. Welfare impacts of rising food prices in rural Ethiopia: A quadratic almost ideal demand system approach.

Dessus, S., Herrera, S., \& De Hoyos, R. (2008). The impact of food inflation on urban poverty and its monetary cost: Some back-ofthe-envelope calculations. Agricultural Economics, 39, 417-429. 
Diiro, G. M., \& Sam, A. G. (2015). Agricultural technology adoption and nonfarm earnings in Uganda: A Semiparametric analysis. The Journal of Developing Areas, 49, 145-162.

D'Souza, A. and Jolliffe, D., 2012. Rising food Price and coping strategies: Household-level evidence from Afghanistan. The Journal of Development Studies, 48(2). https://doi.org/10.1080/00220388. 2011.635422

Friedman, J., \& Levinsohn, J. (2002). The distributional impacts of Indonesia's financial crisis on household welfare: A "rapid response" methodology. The World Bank Economic Review, 16(3), 397-423.

Grant, J. H., Lambert, D. M., \& Foster, K. A. (2010). A seasonal inverse almost ideal demand system for North American fresh tomatoes. Canadian Journalof Agricultural Economics/Revue canadienne d'agroeconomie, 58(2), 215-234.

Groom, B., \& Tak, M. (2015). Welfare analysis of changing food prices: A nonparametric examination of rice policies in India. Food Security, 7(1), 121-141.

Hallegatte, S., Fay, M., \& Barbier, E. B. (2018). Poverty and climate change: Introduction. Environment and Development Economics, 23(3), 217-233.

Hertel, T.W. and Rosch, S.D., 2010. Climate change, agriculture, and poverty. Applied Economic Perspectives and Policy, p.ppq016.

Hertel, T., \& Winters, L. A. (Eds.). (2006). Poverty and the WTO: Impacts of the Doha development agenda, Palgrave-Macmillan and the World Bank Econ. Rev., 18(2), 205-236.

Hertel, T. W., Burke, M. B., \& Lobell, D. B. (2010). The poverty implications of climate-induced crop yield changes by 2030. Global Environmental Change, 20(4), 577-585.

Hoddinott, J. (2006). Shocks and their consequences across and within households in rural Zimbabwe. Journal of Development Studies, 42, 301-321.

IPCC. 2014. Climate Change 2014: Synthesis Report. Contribution of Working Groups I, II and III to the Fifth Assessment Report of the Intergovernmental Panel on Climate Change [Core writing team, R.K. Pachauri and L.a. Meyer (eds.)]. IPCC, Geneva, Switzerland, $151 \mathrm{pp}$.

Ivanic, M. and Martin, W., 2008. Implications of higher global food prices for poverty in low-income countries. Agricultural Economics 39 (2008) supplement, pp.405-416.

Jayne, T.S., Mukumbu, M., Chisvo, M., Tschirley, D.L., Weber, M.T., Zulu, B., Johansson, R.C., Santos, P.M. and Soroko, D., 1999. Successes and challenges of food market reform: Experiences from Kenya, Mozambique, Zambia, and Zimbabwe (no. 1096-201688412).

Knox, J., Hess, T., Daccache, A., \& Wheeler, T. (2012). Climate change impacts on crop productivity in Africa and South Asia. Environmental Research Letters, 7(3), 034032.

Kurukulasuriya, P., Mendelsohn, R., Hassan, R., Benhin, J., Deressa, T., Diop, M., ... \& Mahamadou, A. (2006). Will African agriculture survive climate change?. The World Bank Economic Review, 20(3), 367-388.

Lazaro, E., Sam, A. G., \& Thompson, S. R. (2017). Rice demand in Tanzania: An empirical analysis. Agricultural Economics, 48(2), 187-196.

Li, N., Ker, A., Sam, A. G., \& Aradhyula, S. (2017). Modeling regimedependent agricultural commodity price volatilities. Agricultural Economics, 48(6), 683-691.

Manyatsi, A. M., Mhazo, N., \& Masarirambi, M. T. (2010). Climate variability and changes perceived by rural communities in Swaziland. Research Journal of Environmental and Earth Sciences, 2(3), 165-170.

Mavuso, S. M., Manyatsi, A. M., \& Vilane, B. R. (2015). Climate change impacts, adaptation and coping strategies at Malindza, a rural semiarid area in Swaziland. American Journal of Agriculture and Forestry, 3(3), 86-92.
Mendelsohn, R. (2008). The impact of climate change on agriculture in developing countries. Journal of Natural Resource Policy Research, $1(1), 5-19$.

Minot, N., \& Dewina, R. (2015). Are we overestimating the negative impact of higher food prices? Evidence from Ghana. Agricultural Economics, 46(4), 579-593.

Mkhawani, K., Motadi, S. A., Mabapa, N. S., Mbhenyane, X. G., \& Blaauw, R. (2016). Effects of rising food prices on household food security on femaleheaded households in Runnymede Village, Mopani District, South Africa. South African Journal of Clinical Nutrition, 29(2), 69-74.

Molina, J. A. (1994). Food demand in Spain: An application of the almost ideal system. Journal of Agricultural Economics, 45(2), 252-258.

Mwendera, E. J. (2006). Rural water supply and sanitation (RWSS) coverage in Swaziland: Toward achieving millennium development goals. Physics and Chemistry of the Earth, Parts A/B/C, 31(1516), 681-689.

Nelson, G. C., Rosegrant, M. W., Koo, J., Robertson, R., Sulser, T., Zhu, T., Ringler, C., et al. (2009). Climate change: Impact on agriculture and costs of adaptation. Washington, D.C.: International Food Policy Research Institute.

Nelson, G. C., Rosegrant, M. W., Palazzo, A., Gray, I., Ingersoll, C., Robertson, R., ... Msangi, S. 2010. Food security, farming, and climate change to 2050: scenarios, results, policy options (Vol. 172). Intl Food Policy Res Inst.

Onyutha, C. (2018). African crop production trends are insufficient to guarantee food security in the sub-Saharan region by 2050 owing to persistent poverty. Food Security, 10(5), 1203-1219.

Onyutha, C. (2019). African food insecurity in a changing climate: The roles of science and policy. Food and Energy Security, 8(1), e00160.

Pudney, S. 1989. Modelling individual choice: The econometrics of corners. Kinks and Holes.

Ravallion, M. 1990. Rural welfare effects of food Price changes under induced wage responses: Theory and evidence for Bangladesh Oxford economic papers, new series, 42(3), pp.574-585, Oxford University Press.

Ravallion, M., and Lokshin, M., 2005. Winners and losers from trade reform in Morocco.

Ruel, M. T., Garrett, J. L., Hawkes, C., \& Cohen, M. J. (2009). The food, fuel, and financial crises affect the urban and rural poor disproportionately: A review of the evidence. The Journal of Nutrition, 140(1), 170S-176S.

Sam, A. G., \& Zheng, Y. (2010). Semiparametric estimation of consumer demand systems with micro data. American Journal of Agricultural Economics, 92(1), 246-257.

Sam, A. G. (2010a). Nonparametric estimation of market risk: an application to agricultural commodity futures. Agricultural Finance Review, 70(2), 285-297.

Sam, A. G. (2010b). Impact of government-sponsored pollution prevention practices on environmental compliance and enforcement: evidence from a sample of US manufacturing facilities. Journal of Regulatory Economics, 37(3), 266-286.

Seale, J., Regimi, A., Bernstein, J. 2003. International evidence on food consumption patterns. Tech. Bull. 1904. USDA. October.

Seaman, J. A., Sawdon, G. E., Acidri, J., \& Petty, C. (2014). The household economy approach. Managing the impact of climate change on poverty and food security in developing countries. Climate Risk Management, 4, 59-68.

Shonkwiler, J. S., \& Yen, S. T. (1999). Two-step estimation of a censored system of equations. American Journal of Agricultural Economics, 81(4), 972-982.

Swaziland's INDC-Final-UNFCCC. (29/09/2005). Available at http:/ www4.unfecc.int/submissions/INDC/Published\%20Documents/ Swaziland's\%20INDC.pdf. Accessed on 19/01/2016. 
Sy, A. (2016). Africa: Financing adaptation and mitigation in the World's Most vulnerable region. Africa: Brookings Institution, Africa Growth Initiative.

Terazono, E., 2014. Climate extremes inflate food prices; the business of global food security. Available at http://www.ft.com/cms/s/2/ 5c4500fc-a518-11e3-8988-00144feab7de.Html\#axzz3Yhpsup00. Accessed on 19/01/2016.

Thornton, P. K., Jones, P. G., Alagarswamy, G., Andresen, J., \& Herrero, M. (2010). Adapting to climate change: Agricultural system and household impacts in East Africa. Agricultural Systems, 103(2), 73-82.

Vermeulen, S. J., Campbell, B. M., \& Ingram, J. S. (2012). Climate change and food systems. Annual Review of Environment and Resources, 37, 195-222.

Wadud, M. A. (2006). An analysis of meat demand in Bangladesh using the almost ideal demand system. The Empirical Economics Letters, $5(1), 29-35$.

Wheeler, T., \& von Braun, J. (2013). Climate change impacts on global food security. Science, 341(6145), 508-513.

Wodon, Q., \& Zaman, H. (2010). Higher food prices in sub-Saharan Africa: Poverty impact and policy responses. The World Bank Research Observer, 25(1), 157-176.

World Food Programme Swaziland Country Brief. 2017. Accessible at https://reliefweb.int/sites/reliefweb.int/files/resources/wfp272254_ 1.pdf.

Yen, S. T., \& Lin, B. H. (2006). A sample selection approach to censored demand systems. American Journal of Agricultural Economics, 88(3), 742-749.

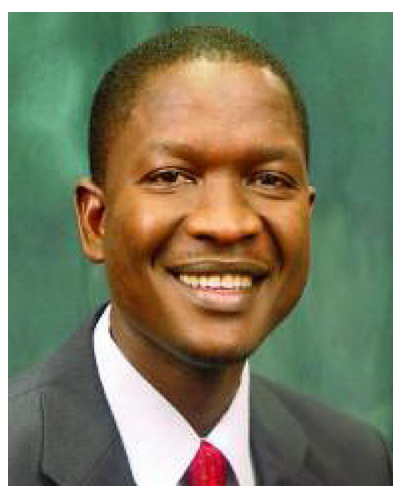

Abdoul Sam 's scholarly interests center on the use of parametric and nonparametric econometrics to explore substantive economic issues primarily in environmental economics and development economics. Abdoul's research in environmental economics explores the determinants, effects, and effectiveness of voluntary pollution reduction programs, which have become an important element of the environmental protection toolkit in the US and many other countries. His recent research in development economics uses household-level data to investigate whether land ownership by women in developing countries promotes their empowerment and to explain the adoption of financial and technological innovations by farmers in developing countries. Abdoul's research has been published in prominent peer-reviewed journals including the Journal of Law and Economics, the Journal of Financial and Quantitative Analysis, the Journal of Environmental Economics and Management, Land Economics, the American Journal of Agricultural Economics, Regional Science and Urban Economics, World Development. Abdoul has served as advisor to several $\mathrm{PhD}$ students and Master's degree students.

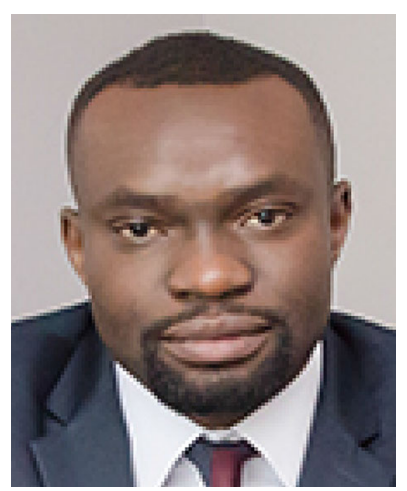

Babatunde Abidoye is a visiting senior fellow at London School of Economics and a Senior Economist with the United Nations Development Programme (UNDP). Babatunde led various initiatives on the economics of climate change adaptation in Africa, and Asia and the Pacific regions with UNDP; and the impact evaluation portfolio of the Nature Climate and Energy (NCE) in 10+ countries, by applying experimental and nonexperimental methods to understand the impact of climate adaptation investments on the SDGs. He is also an Affiliate Professor at George Mason University and an Extraordinary Lecturer at the University of Pretoria, South Africa. Babatunde's work focuses on understanding interventions that can help alleviate poverty and achieve SDGs under different risks and uncertainties such as climate change and conflicts. This includes understanding effectiveness of current strategies and testing new methods of adapting to climate change using experimental and non-experimental techniques. Babatunde's research has been published in prominent peer-reviewed journals including the American Journal of Agriculutural Economics, Environmental and Resource Economics and Journal of African Economies.

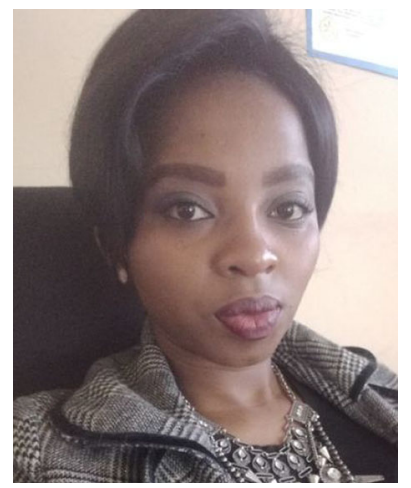

Ms. Sihle Mashaba is an Economist at the Ministry of Economic Planning and Development in Eswatini. She graduated with a Masters in Agricultural Economics from University of Pretoria. She was funded under the Mastercard Scholars Foundation scholarship. She was a research assistant at Land Matrix initiative and Environmental Assessment Practitioner at Tshikovha Environmental and South Africa.
Communication Consulting in 